\title{
Successful surgical treatment of spear wounds in a Hawksbill Turtle, Eretmochelys imbricata (Testudines: Cheloniidae)
}

\author{
D.P. Moore ${ }^{1}$, E.H. Williams, Jr. ${ }^{2}$, A.A. Mignucci-Giannoni ${ }^{3}$, L. Bunkley-Williams ${ }^{4}$ \& \\ W.G. Dyer ${ }^{5}$ (deceased) \\ 1 Caribbean Center of Marine Studies, Veterinary Clinic - Clinica. Veterinaria, P.O. Box 585, Lajas, Puerto Rico \\ 00667-0585 Potreen@coqui.net \\ 2 Caribbean Aquatic Animal Health Project, Department of Marine Sciences, University of Puerto Rico, P.O. Box 9013, \\ Mayagüez, Puerto Rico 00861-9013; ewilliams@uprm.edu \\ 3 Red Caribeña de Varamientos - Caribbean Stranding Network, P.O. Box 361715, San Juan, Puerto Rico 00936-1715 \\ mignucci@caribe.net \\ 4 Department of Biology, University of Puerto Rico, P.O. Box 9012, Mayagüez, Puerto Rico 00861-9012 lwilliams@ \\ uprm.edu \\ 5 formerly College of Science, Southern Illinois University \\ Author for correspondence: EHW, address as above. Telephone: 1 (787) 832-4040 X 3929; FAX: 1-787-834-3673; \\ ewilliams@uprm.edu; Potreen@coqui.net
}

Received 15-VII-2007. C Corrected 01-XII-2007. Accepted 13-II-200.

\begin{abstract}
Sea Turtles are frequently poached by spearing in the neck region and subsequently holding them alive until slaughter. Thus the ability of stranding networks to repair and rehabilitate these animals is of interest. Two Hawksbill Turtles, Eretmochelys imbricata, illegally collected by spear fishing 8 May 1993 were confiscated by the Puerto Rico Maritime Police and referred to the Caribbean Stranding Network for rehabilitation (Case \# NEPCH136). The lacerated cervical region of both animals was surgically repaired. One adult male turtle $67 \mathrm{~cm}$ in carapace length and weighing $46.8 \mathrm{~km}$ lacking additional injuries recovered and was released (flipper tags QQD915, QQD916). A juvenile female was $46.0 \mathrm{~cm}$ in carapace length and $15.2 \mathrm{~kg}$ in weight with additional injuries succumbed to bacteria (Proteus mirabilis and Serratia rubridea) infections despite treatment with ampicillin trihydrate. A necropsy found routine numbers and diversity of parasites that were reported elsewhere. This result demonstrates that speared sea turtles without further complications can be rehabilitated. Since this somewhat early surgery, new techniques have been developed to even more successfully manage seaturtle wounds. Rev. Biol. Trop. 56 (Suppl. 1): 271-276. Epub 2008 May 30.
\end{abstract}

Key words: turtle rehabilitation, turtle wounds, turtle treatment, cervical repair, Proteus mirabilis, Serratia rubridea.

The Hawksbill, Eretmochelys imbricata (Linnaeus), the most tropical of all sea turtles (Testudines: Cheloniidae) is distributed throughout the central Atlantic and IndoPacific regions. It is considered endangered throughout its range, as populations have been drastically reduced by intense exploitation by humans. In Puerto Rico, larger animals are hunted for their meat while virtually any size animal is killed for its commercially valuable scutes or stuffed as a taxidermy show piece. For centuries, specialized artisans have crafted jewelry and curios out of these thick, decorative scutes. The Caribbean Stranding Network (CSN) and the Chelonia Society of Puerto Rico have cooperated in extensive campaigns and public awareness programs focused on education to help save this species. Case work of CSN is an important component of this public educational and information process. This paper presents a Hawksbill case submitted to CSN for rehabilitation. 


\section{MATERIALS AND METHODS}

Two hawksbill turtles with spear wounds in the cervical region were found aboard a boat off La Parguera by the Maritime Police. The animals were confiscated and reported to the CSN (case \# NEPCH136). Both animals were given emergency medical care (pressure bandages applied to the puncture wounds to prevent further hemorrhage) on site before being transported to the CSN facility at the Magueyes Island Marine Laboratories, Department of Marine Sciences, University of Puerto Rico at Mayagüez, 13:30 hrs 8 May 1993. Standard rescue and rehabilitation procedures of the time were followed. The animals were placed on a dampened foam support cushion to prevent damage to their plastron during transport and the carapaces were kept moist by applying water. Lactated Ringers solution was administered intravenously for rehydration. Exploratory surgery was preformed on both animals to assess the extent of the damage (Fig.
1). Ketamine hydrochloride was used for local anesthesia intramuscularly at a dosage of 40 $\mathrm{mg} / \mathrm{kg}$. An endotracheal tube was placed in the trachea to provide respiratory assistance in the event of respiratory arrest. Lidocaine was also administered locally in the area of the puncture wounds. Antibiotic therapy was conducted for 10 days providing ampicillin trihydrate at a dosage of $4 \mathrm{mg} / \mathrm{kg}$ intramuscularly once a day. The trachea of the female and musculature of the male was surgically repaired using polyglycolic acid (Vicryl ${ }^{\circledR}$ polyglactin 910 ) sutures, which are absorbed in 3-4 weeks. The wounds of the male were closed with simple interrupted suture patterns. Complete blood and biochemical analyses were conducted on both animals (Appendix 1), including bacteriological analysis of blood from the heart, liver, and thymus gland; and serosanguinous fluid. During rehabilitation the turtles were fed twice daily with approximately $150 \mathrm{ml}$ of fish gruel comprised of locally caught sardines, fresh water and Sea World vitamins via a stomach tube and

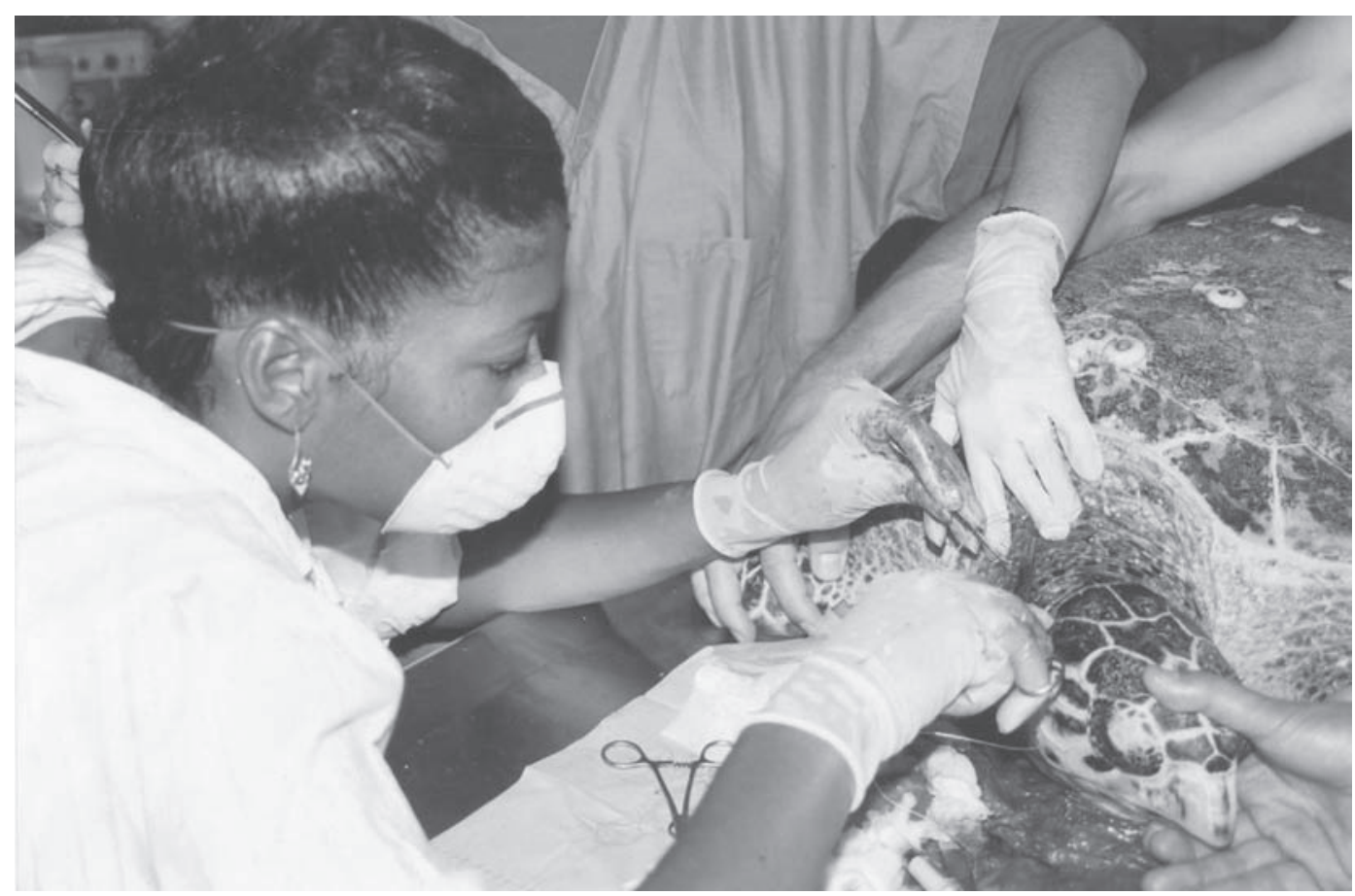

Fig. 1. Debra P. Moore performing exploratory surgery on a Hawksbill Turtle, Eretmochelys imbricata, at the Magueyes Island Marine Laboratories off La Parguera, Puerto Rico. 
monitored for signs of aspiration pneumonia. Histological samples of all major organs of the turtle that died were preserved in buffered formalin, embedded in paraffin, sectioned, stained in hematoxylin and eosin, and mounted on microscope slides.

\section{RESULTS}

One turtle was a large, adult male, carapace length $67.0 \mathrm{~cm}$, and $46.8 \mathrm{~kg}$ in weight; and the other a smaller, juvenile female, carapace length $46.0 \mathrm{~cm}$, and $15.2 \mathrm{~kg}$. A veterinary examination revealed that the animals, in all aspects besides their wounds, were in good physical condition with excellent muscle mass. Their carapaces and plastrons appeared normal except for the presence of a few barnacles (Chelonibia testudinaria, Fig. 1). The female was lethargic. She was dehydrated and had two 2-cm puncture wounds on the cranio-dorsal and mid-ventral surfaces of the neck. The craniodorsal wound penetrated into the superficial musculature and the ventral puncture wound was deeper with a partial severance of the trachea. Palpation demonstrated subcutaneous emphysema. The larger male had a 2-cm puncture wound on the cranio-dorsal surface of the neck. The puncture wound proceeded distally and deeply into the musculature causing severe muscle damage and severance of blood vessels associated with the jugular vein and carotid artery tributaries. Limited bleeding occurred. The blood analysis showed both turtles were severely anemic (Appendix 1).

During surgery a 2-cm tear was found between the fifth and sixth tracheal rings of the female. Upon inspiration, the animal would gasp for air. The tear was surgically repaired and the animal was placed on antibiotic therapy for seven days. The musculature of the male was surgically repaired.

The female was placed on a foam pad with a saltwater sprinkler system to keep the carapace and plastron moist. Lactated Ringers solution was administered intraceolomically at a rate of $16 \mathrm{ml} / \mathrm{kg}$ for both animals over a 24 hour period for rehydration. On day three in rehabilitation, she was slowly fed twice daily and monitored for signs of aspiration pneumonia. The male was placed in a shallow pool, administered antibiotic therapy (ampicillin trihydrate at a dosage of $4 \mathrm{mg} / \mathrm{kg}$ intramuscularly once a day) for seven days, and fed 10-12 locally caught sardines per day which it readily consumed.

On day 13, the female was placed in a pool and monitored, but it died at 09:00 hrs on day 16. A necropsy revealed that the pleural/peritoneal lining, pericardial sac, and anterior mesenteric vessels contained a very gelatinous watery translucent fluid (1.012 specific gravity) which exuded from the cut surfaces. The pericardium and subcutaneous tissue had a transudative accumulation of fluid as well. These findings indicate edema. The anterior mesenteric vessels were congested with blood. There was an intense dark discolored area mottled with pale spots (histologically shown to be ischemia) and soft, dark hemorrhagic areas histologically shown to be necrosis in the heart musculature. The thymus gland was intensely red. Both lungs were edematous and had ecchymotic hemorrhage throughout the tissue. There was approximately one liter of serosanguinous fluid in the coelomic cavity.

The cranial dorsal surface of the neck had a 2-cm superficial puncture wound and the mid-ventral wound had a yellow discoloration of the subcutaneous fascia. At necropsy, the dorsal anterior trachea was transected ventrally $(1.3 \mathrm{~cm})$ between the second and third tracheal ring. The surrounding fascia and the musculature were yellow and necrotic. The posterior oropharynx and anterior esophagus had a 2-cm puncture wound in the mucosa, submucosa, and adjacent musculature. A yellow caseous material was found in the fascia between the anterior esophagus and trachea.

Bacteriological samples from the blood of the liver, and thymus gland were negative for growth. The heart blood was positive for Serratia rubridea and the serosanguinous fluid for Proteus mirabilis. Histological samples from these organs demonstrated an inflammatory response. No lesions occurred in the 
gastrointestinal tract. The unremarkable parasitic population from this animal was reported by Dyer et al. (1995).

The male turtle recovered without complications. The animal was released on day 25 (1 June 1993, flipper tags no. QQD915, QQD916).

\section{DISCUSSION}

The poachers of these turtles were prosecuted by the U.S. Federal Court in Puerto Rico 8 September 1993. The three men were local residents of the east coast of Puerto Rico, and were found guilty of violating the Endangered Species Act. They were sentenced 14 December 1993.

Surgical repair of injured wild sea turtles is becoming more common (e.g., Naganobu et al. 2000, Jaeger et al. 2003, Lewbart et al. 2005), but many natural resource organizations are unaware of these advances and may unnecessarily euthanize injured turtles. Thus publishing details of successful surgical and rehabilitation methods is useful. Since the surgery we describe, better techniques have been developed and tested. It has proven almost impossible to sanitize wounds contaminated with sea water sufficiently to close them without allowing bacterial abscesses to develop. Therefore, wounds are now allowed to remain open for healing whenever possible only closing critical areas such as the trachea and possibly larger muscles. The male turtle was released after 25 days of rehabilitation. We now know than bacterial abscesses may develop months after surgery. The turtle should have been held longer for observation.

Sea turtles are frequently poached by spearing in the neck (Julie 1992) and then held alive until slaughtered. Thus turtles with these injuries may be often referred to rehabilitation facilities. The importance of this type of injury made our attempt to rehabilitate animals with these injuries of particular interest. One turtle lacking additional injuries recovered and was released. This result demonstrates that sea turtles speared in the neck, but without further complications, can be rehabilitated.

\section{ACKNOWLEDGMENTS}

We thank James J. Woytash, Veterinary Pathologist, U.S. Naval Hospital Roosevelt Roads, Puerto Rico, for histological analysis; Irma Hernandez, Laboratorio Clinico, Centro Medico, Mayagüez, Puerto Rico, for analyzing blood samples; Charles A. Manire, Mote Marine Laboratory, Sarasota, Florida, and Richard S. Legore, LeGore Environmental Associates, Inc., Holmes Beach, Florida, for reviews of the manuscript; and CSN volunteers and the Commonwealth Department of Natural and Environmental Resources for assistance.

\section{RESUMEN}

Las tortugas marinas sufren frecuentemente de ataques con lanzas en la región del cuello, lo que implica que las mantienen vivas hasta destazarlas. Por tanto, la habilidad de las redes de rescate de animales varados para curar y rehabilitar estos animales, ha cobrado interés. Dos tortugas de carey, Eretmochelys imbricata, recolectadas ilegalmente por medio de la pesca con lanza, el 8 de mayo de 1993, fueron confiscadas por la Policía Marítima de Puerto Rico y enviadas a la "Caribbean Stranding Network", para la rehabilitación de dichas tortugas (Caso \# NEPCH136). La región cervical lacerada de ambas tortugas fue sometida a cirugía y reparada de esta manera. Una de la tortugas, un macho adulto con un caparazón de $67 \mathrm{~cm}$ de largo y 46.8 kg de peso, que carecía de otras heridas, se recuperó y fue liberada (marcas de aleta QQD915, QQD916). La otra, una hembra joven con un caparazón de $46.0 \mathrm{~cm}$ y con un peso de $15.2 \mathrm{~kg}$, tenía otras heridas, las cuales fueron infectadas por bacterias (Proteus mirabilis y Serratia rubridea), a pesar del tratamiento con trihidrato de ampicilina. Una necropsia reveló la existencia de numerosos y diversidad de parásitos que fueron reportados en otras regiones. El resultado de este procedimiento demostró que las tortugas heridas con lanzas, que no presentan otras complicaciones, pueden ser rehabilitadas. Esta cirugía, algo temprana, ha dado lugar a que se desarrollen nuevas técnicas para un manejo exitoso de las heridas de las tortugas marinas.

Palabras clave: rehabilitación de tortugas, heridas de tortugas, tratamiento de tortugas, curación cervical, Proteus mirabilis, Serratia rubridea. 


\section{REFERENCES}

Dyer, W.G., E.H. Williams, Jr., L. Bunkley-Williams \& D.P. Moore. 1995. Some digeneans (Trematoda) of the hawksbill turtle, Eretmochelys imbricata imbricata (Testudines: Cheloniidae) from Puerto Rico. J. Helminthol. Soc. Wash. 62: 13-17.

Jaeger, G.H., M.A. Wosar, C.A. Harms, \& G.A. Lewbart. 2003. Use of a supraplastron approach to the coelomic cavity for repair of an esophageal tear in a loggerhead sea turtle. J. Amer. Vet. Med. Assoc. 223: 353-355.

Julie, A. 1992. WIDECAST Sea Turtle Recovery Action Plan for the British Virgin Islands. Caribbean Environment Program Technical Report no. 15, 116 p.
Lewbart, G.A., J. Kishimori, \& L.S. Christian. 2005. The North Carolina State University College of Veterinary Medicine Turtle Rescue Team: a model for a successful wild-reptile clinic. J. Vet. Med. Educ. 32: 377-381.

Moore, D. P., L. Bunkley-Williams, E. H. Williams, Jr., A. A. Mignucci-Giannoni, F. E. Tippett, R. A. Montoya, and W. G. Dyer. 2007. Successful surgical treatment of spear wounds in a Hawksbill Turtle, Eretmochelys imbricata; and cardiac failure of an Antillian Manatee, Trichechus manatus manatus, in Puerto Rico. Proc. Ass. Mar. Labs. Carib. 33: 93.

Naganobu, K., H. Ogawa, N. Oyadomari, \& M. Sugimoto. 2000. Surgical repair of a depressed fracture in a green sea turtle, Chelonia mydas. J. Vet. Med. Sci. 62: 103-104. 


\section{APPENDIX 1}

Blood analysis of two hawksbill turtles (NEPCH136)

Parameter

Female

Male

CBC (Complete Blood Count without differential)*

WBC X $10^{3}$

RBC

$\mathrm{Hgb}$

Hct\%

MCV

\section{BIOCHEMISTRY}

Chloride

Sodium

Potassium

Calcium

Phosphorus

Cholesterol

Creatine

Glucose

Bun

Uric Acid

Total Protein

Albumin

Amylase

Triglycerides

SGoT

SGPT

CPK

Alk Phosphatase
$104 \mathrm{mEq}$

$79.8 \times 10^{3}$

count lost

$2.9 \mathrm{gm} / \mathrm{dl}$

2.1

$172.6 \mathrm{fl}$

$152 \mathrm{mEq}$

$4.4 \mathrm{mEq}$

$4.5 \mathrm{mEq}$

$9.4 \mathrm{mg} / \mathrm{dl}$

$64 \mathrm{mg} / \mathrm{dl}$

$0.5 \mathrm{mg} / \mathrm{dl}$

$84 \mathrm{mg} / \mathrm{dl}$

$91 \mathrm{mg} / \mathrm{dl}$

$1.3 \mathrm{mg} / \mathrm{dl}$

$4.2 \mathrm{gm} / \mathrm{dl}$

$1.0 \mathrm{gm} / \mathrm{dl}$

$518 \mathrm{u} / \mathrm{l}$

$26 \mathrm{mg} / \mathrm{dl}$

$786 \mathrm{u} / \mathrm{l}$

$40 \mathrm{u} / \mathrm{l}$

$65 \mathrm{u} / \mathrm{l}$
$20.7 \times 10^{3}$

$4.4 \times 10^{6} / \mu \mathrm{l}$

$9.7 \mathrm{gm} / \mathrm{dl}$

5.3

$126.4 \mathrm{fl}$

$113 \mathrm{mEq}$

$153 \mathrm{mEq}$

$4.6 \mathrm{mEq}$

$5.4 \mathrm{mEq}$

$7.6 \mathrm{mg} / \mathrm{dl}$

$52 \mathrm{mg} / \mathrm{dl}$

$0.5 \mathrm{mg} / \mathrm{dl}$

$84 \mathrm{mg} / \mathrm{dl}$

$95 \mathrm{mg} / \mathrm{dl}$

$1.9 \mathrm{mg} / \mathrm{dl}$

$4.0 \mathrm{gm} / \mathrm{dl}$

$0.8 \mathrm{gm} / \mathrm{dl}$

$480 \mathrm{u} / \mathrm{l}$

$78 \mathrm{mg} / \mathrm{dl}$

824 u/l

$49 \mathrm{u} / \mathrm{l}$

159,360 u/l

$67 \mathrm{u} / \mathrm{l}$

*Samples were grossly hemolyzed; CPK = creatine phosphokinase; Hct\% = hematocrit percentage; Hgb = hemoglobin; $\mathrm{MCV}=$ mean corpuscular volume; $\mathrm{mEq}=$ milliequivalent; $\mathrm{RBC}=$ red blood cells, SGot $=$ serum glutamic oxaloacetic transaminase; $\mathrm{SGPT}=$ serum glutamic pyruvic transaminase; $\mathrm{WBC}=$ white blood cells. 